$\frac{30}{4110187} \mathrm{gs} \quad I 30039$

UK $0221-6$

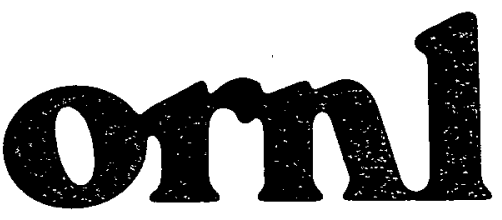

ORNL/TM-10341

\title{
Evaluation of Selected Detector Systems for Products Formed in the Atmospheric Hydrolysis of Uranium Hexafluoride
}

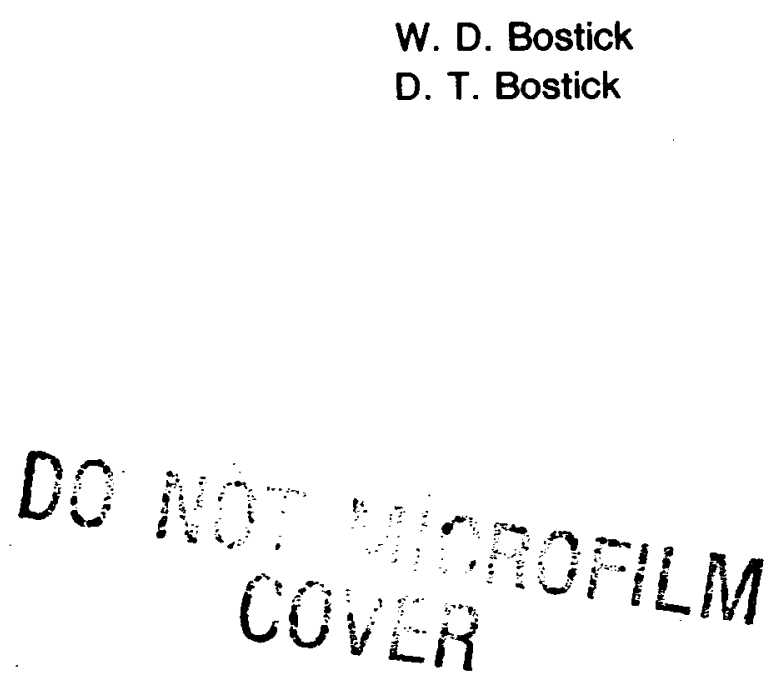

OPERATED BY

MARTIN MARIETTA ENERGY SYSTEMS, INC.

FOR THE UNITED STATES

DEPARTMENT OF ENERGY 


\section{DISCLAIMER}

This report was prepared as an account of work sponsored by an agency of the United States Government. Neither the United States Government nor any agency Thereof, nor any of their employees, makes any warranty, express or implied, or assumes any legal liability or responsibility for the accuracy, completeness, or usefulness of any information, apparatus, product, or process disclosed, or represents that its use would not infringe privately owned rights. Reference herein to any specific commercial product, process, or service by trade name, trademark, manufacturer, or otherwise does not necessarily constitute or imply its endorsement, recommendation, or favoring by the United States Government or any agency thereof. The views and opinions of authors expressed herein do not necessarily state or reflect those of the United States Government or any agency thereof. 


\section{DISCLAIMER}

Portions of this document may be illegible in electronic image products. Images are produced from the best available original document. 


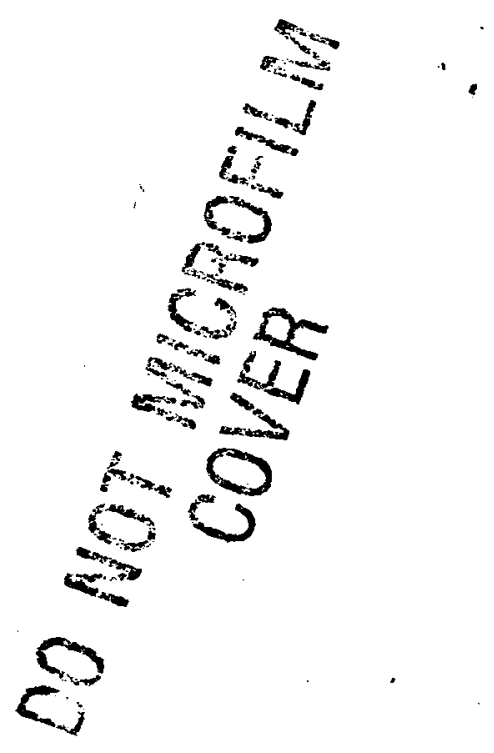

Printed in the United States of America. Available from National Technical Information Service

U.S. Department of Commerce

5285 Port Royal Road, Springfield, Virginia 22161

NTIS price codes-Printed Copy: A03; Microfiche A01

This report was prepared as an account of work sponsored by an agency of the United States Government. Neither the United States Government nor any agency thereof, nor any of their employees, makes any warranty, express or implied, or assumes any legal liability or responsibility for the accuracy, completeness, or usefulness of any information, apparatus, product, or process disclosed, or represents that its use would not infringe privately owned rights. Reference herein to any specific commercial product, process, or service by trade name, trademark, manufacturer, or otherwise, does not necessarily constitute or imply its endorsement, recommendation, or favaring by the United States Government or any agency thereof. The views and opinions of authors expressed herein do not necessarily state or reflect those of the United States Government or any agency thereof. 
This document is PUBLICLY RELEASABLE Bam Soab Authorizing Official Date: $\quad 8 \cdot 24-0+$
W. D. Bostick

Process Support Division

Oak Ridge Gaseous Diffusion Plant

and

D. T. Bostick

Analytical Chemistry Division

Oak Ridge National Laboratory

Date Published - March 1987

NOTICE This document contains information of a preliminary nature. It is subject to revision or correction and therefore does not represent a final report.

OAK RIDGE NATIONAL LABORATORY

Oak Ridge, Tennessee 37831

operated by

MARTIN MARIETTA ENERGY SYSTEMS, INC.

for the

DEPARTMENT OF ENERGY
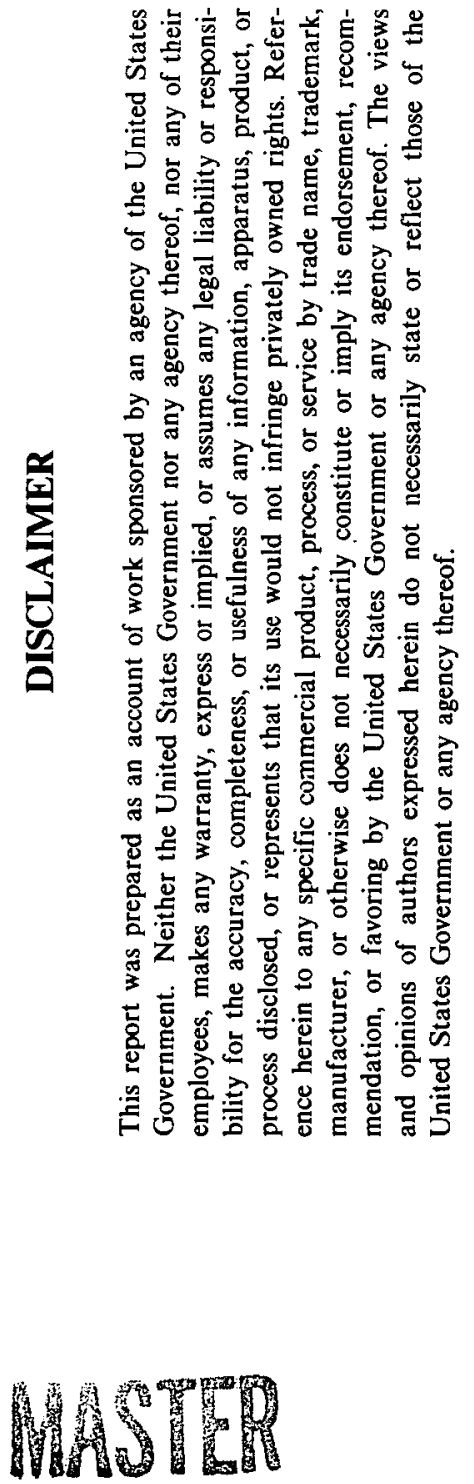
I. INTRODUCTION . . . . . . . . . . . . . . . . . . . . . . . . . 1

II. PRINCIPLES OF AEROSOL DETECTION . . . . . . . . . . . . . . . . . 1
A. Photometric Detection . . . . . . . . . . . . . . . . . . 1
B. Gas Detector Tubes... . . . . . . . . . . . . . . . . . 3
C. Electrochemical Sensor .. . . . . . . . . . . . . 3

III. EXPERIMENTAL DESIGN . . . . . . . . . . . . . . . . . . . . 4

A. Photometric Detection . . . . . . . . . . . . . . . . 4

B. Gas Detector Tubes... . . . . . . . . . . . . . . . . 7

C. Sensidyne HF Alert Monitor . . . . . . . . . . . . . . . 12

D. UF $\mathrm{UF}_{6}$ Release Facility . . . . . . . . . . . . . . . . . 13

E. Sampling and Chemical Analysis... . . . . . . . . . . 13

IV. EXPERIMENTAL RESULTS . . . . . . . . . . . . . . . . . . . . 15

A. Photometric Detection . . . . . . . . . . . . . . . . . . 15

B. Hydrogen Fluoride Detector Tubes . . . . . . . . . . . . . 19

C. Sensidyne HF Alert Monitor . . . . . . . . . . . . . . . 20

V. COMPARISON OF DETECTION DEVICES AND THEIR RESPONSE . . . . . . 23

VI. RECOMMENDATIONS . . . . . . . . . . . . . . . . . . . . . . 24

A. Laser UF 6 Release Monitor . . . . . . . . . . . . . . . . 24

B. HF Gas Detector Tube . . . . . . . . . . . . . . . . . . 26

C. Sensidyne HF Alert Monitor. . . . . . . . . . . . . . 28

ACKNOWLEDGMENTS . . . . . . . . . . . . . . 28

REFERENCES . . . . . . . . . . . . . . . . . . . . . . . . 29

DISTRIBUTION LIST . . . . . . . . . . . . . . . . . . . . . . . 30 


\section{LIST OF FIGURES}

1. Schematic of the expanded beam transmission system

2. Detector amplifier circuit

3. Block diagram of buffer and subtraction circuit

4. Summary of signal amplification and data output devices for CTB, ETB and Reflectance Photodiodes

5. Photograph of Gastec HF detector tubes after sampling UF -release $^{-}$ containment chamber (see also Table 5 of text)

6. Nominal scale calibration (HF, Ppm) ys stain migration distance for Gastec HF detector tube

7. "Exploded" view of release chamber, indicating location of sampling and detection ports

8. Digital and analog data for CTB and ETB optical signals after UF 6 release

9. Tracing of a segment of analog laser light transmission data at initial time of $\mathrm{UF}_{6}$ release

10. Response of Sensidyne $\mathrm{HF}$ alert to experimental release of $\mathrm{UF}_{6}$ : effect of forced convection within chamber

11. Comparison of airborne uranium concentration (sampled at "side" port, CF. Fig. 7) vs absorbance of laser beam during UF -release $^{-}$ experiment

12. Comparison of airborne HF concentration (sampled at "side" port, using Gastec HF detector tubes) vs absorption of laser beam during $\mathrm{UF}_{6}$-release experiment 


\section{LIST OF TABLES}

1. Health effects of $\mathrm{UF}_{6}$ hydrolysis products

2. Guidelines for indefinite exposure to airborne soluble uranium and hydrofluoric acid

3. Characteristics of condensed beam and expanded beam transmission systems

4. Empirical scale reading correction factors for use with Gastec HF detector tubes

5. Effect of ambient room lighting on photodiode dark current

6. Results from sampling with use of Gastec HF detector tubes

7. Post-sampling stain migration on Gastec HF detector tubes

8. Comparison of Sensidyne HF alert response to chemical composition

9. Experimental releases of $\mathrm{UF}_{6}$ into a $6 \mathrm{~m}^{3}$ chamber 


\section{INTRODUCTION}

When gaseous uranium hexafluoride $\left(U F_{6}\right)$ is released into the atmosphere (as may occur from the rupture or failure of cylinders, transfer lines, or reaction vessels containing liquid or gaseous $U F_{6}$ $(1-3)$ ), it is rapidly hydrolyzed by ambient moisture to form a toxic aerosol (4) comprised of uranyl fluoride $\left(\mathrm{UO}_{2} \mathrm{~F}_{2}\right)$ particles and hydrogen fluoride vapor (HF):

$$
\mathrm{UF}_{6}(\mathrm{~g})+2 \mathrm{H}_{2} \mathrm{O}(\mathrm{g})-\cdots \cdot \mathrm{UO}_{2} \mathrm{~F}_{2}(\mathrm{~s})+4 \mathrm{HF}(\mathrm{g})
$$

The health effects of these products and the recommended safe exposure limits are listed in Tables 1 and 2, respectively. (Note that since uranyl fluoride can have both chemical and radiological toxicity, exposure limits are related to the degree of enrichment of uranium in the compound).

Obviously, sensitive detection of $U F_{6}$ hydrolysis products, either by discontinuous sampling or by continuous or near real-time monitoring, is an important safety consideration for DOE contractors handling large quantities of $\mathrm{UF}_{6}$. Automated continuous or rapid intermittent remote sensing of these reaction products can provide an alarm signal when a preselected threshold value has been exceeded (absolute response) or when a significant emission excursion has occurred (rate of change of response).

In this report we evaluate the performance of selected devices for the detection of airborne materials formed in the release of liquid UF 6 $(\approx 1.3 \mathrm{~g})$ into an enclosed volume of $6 \mathrm{~m}^{3}$; these experiments were initiated on October 23, 1986. The detection principles investigated are described below.

\section{PRINCIPLES OF AEROSOL PRODUCT DETECTION}

A. Photometric Detection

Airborne uranyl fluoride particles (Equation 1) are formed with average aerodynamic sizes in the range of approximately 0.2 to $0.8 \mu \mathrm{m}$ (5). Particles of this size interact with visible light to produce Mie-type scattering, the intensity of which is strongly concentrated in 
Table 1. Health effects of $U_{6}$ hydrolysis products (4)

\begin{tabular}{|c|c|c|c|c|}
\hline Species & Health Effect & \multicolumn{2}{|c|}{$\begin{array}{l}\text { Exposure Level } \\
\left(\mathrm{mg} / \mathrm{m}^{3}\right) \quad\left(\mathrm{mg} / \mathrm{m}^{3}\right) \times(\mathrm{min})\end{array}$} & \multirow{2}{*}{$\begin{array}{l}\begin{array}{l}\text { Exposure } \\
\text { Time }\end{array} \\
\text { Indefinite }\end{array}$} \\
\hline $\mathrm{UO}_{2} \mathrm{~F}_{2}$ & 50 o Lethality & $\cdots$ & 35,000 & \\
\hline & Renal Injury & $\cdots$ & $\begin{array}{r}1,250 \\
750\end{array}$ & $\begin{array}{l}<30 \mathrm{~min} \\
>60 \mathrm{~min}\end{array}$ \\
\hline & No Effect & $\ldots$ & $\begin{array}{l}650 \\
390\end{array}$ & $\begin{array}{l}<30 \mathrm{~min} \\
>60 \mathrm{~min}\end{array}$ \\
\hline
\end{tabular}

HF

Detection by

1

$-\cdots$

Indefinite Sme11

Irritation

26

13

$\cdots$

$<10 \mathrm{~min}$

$>10 \mathrm{~min}$

Lethal

53,000

0 to $60 \mathrm{~min}$

Table 2. Guidelines for indefinite exposure to airborne soluble uranium and hydrofluoric acid

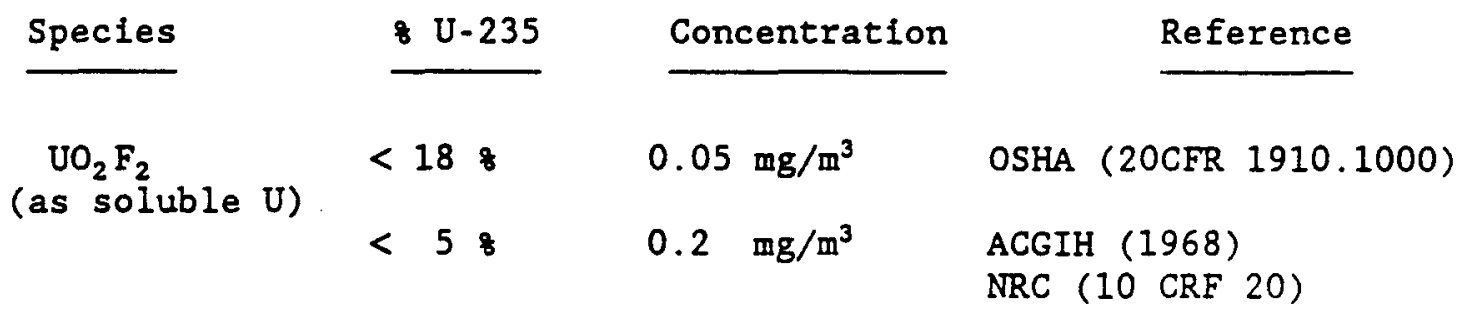

$\begin{array}{cccc}\text { HF } & \cdots & 3 \mathrm{ppm} & \text { OSHA } \\ \text { (as fluoride) } & & 3 \mathrm{ppm}(2 \mathrm{mg} / \mathrm{L}) & \text { ACGIH (1979) }\end{array}$

*OSHA = Occupational Safety and Health Administration ACGIH - American Conference of Government Industrial Hygienists NRC = Nuclear Regulatory Commission 
the forward direction (6). In addition, hydrated $\mathrm{HF}$ can form a mist or fog which can contribute to light scatter (7).

Although it is not inherently selective for $\mathrm{UF}_{6}$ hydrolysis products, light scatter has been shown to be a very sensitive means to remotely monitor the relative concentration of airborne products $(6,8)$. Monitoring the change of light transmission or light scatter response within an enclosed volume (such as an autoclave) enhances its selectivity.

Since the scattered light intensity is expected to have a strong angular dependence, two photometric techniques were used to follow the release of $U_{6}$ within the experimental chamber. The first technique was based on the attenuation of a laser beam traversing the release vessel by the $\mathrm{UO}_{2} \mathrm{~F}_{2}$ aerosol. The loss in optical signal was correlated with the amount of suspended uranyl particulates to determine the efficiency for which the optical transmission signal could detect the release of $U F_{6}$. The second photometric technique was based on the measurement of light scattered by $\mathrm{UO}_{2} \mathrm{~F}_{2}$ at a 90 degree angle from the incident laser beam. The increase in the scattered optical signal following $U_{6}$ release was compared with results obtained with the optical transmission technique to select the preferred system for the detection of $\mathrm{UF}_{6}$ release in containment vessels.

\section{B. Gas Detector Tubes}

Gas detector tubes contain a selective reagent adsorbed onto a silica gel matrix. A known volume of air, containing the constituent to be measured, is drawn through the tube with use of a manual syringe pump. The reactive constituent in the gas sample contacts the adsorbed reagent, producing a colored reaction product or "stain"; the length of the stain produced within the tube is proportional to the concentration of the sought-for substance.

\section{Electrochemical Sensor}

The HF Alert unit is manufactured by Sensidyne, Inc., Largo Florida. Acidic HF vapor diffusing through a thin, porous hydrophobic membrane into an internal electrolyte solution produces a galvanic response proportional to the partial pressure of the acidic component. 
III. EXPERIMENTAL DESIGN

A. Photometric Detection

Two laser systems were set up for the measurement of optical light transmission during the release experiment. The condensed transmission beam (CTB) system contains only the most basic optical components required to perform the transmission experiment. The expanded transmission beam (ETB) system contains additional or higher quality optical components. The performance of these two systems during the release experiment were compared to determine the most reliable and economical equipment required for $U_{F_{8}}$ detection based on a light transmission technique.

A schematic of the EIB system is given below (Figure 1); Tabie 3 summarizes the differences between the two optical transmission systems. The light source for both units is a helium-neon (HeNe) laser, providing $1 \mathrm{~mW}$ of optical power at $633 \mathrm{~nm}$. The HeNe laser in the CTB system transmits unpolarized monochromatic light, whereas the ETB system used a polarized HeNe laser. An optical beam expander was attached to the polarized HeNe laser to expand the optical beam diameter from $0.6 \mathrm{~mm}$ to $6 \mathrm{~mm}$. The $10 \mathrm{X}$ beam expander was added to the optical system to decrease the effect of ambient room dust on the stability of the optical signal and also to increase the volume of the containment vessel sampled by the optical beam. The CTB system did not include a beam expander; its optical signal stability would then be compared with that of the ETB system. A microscope slide, aligned obliquely to the laser beam, was used to deflect a portion of the laser intensity through a $633 \mathrm{~nm}$ optical filter to a $1 \mathrm{~cm}$ diameter silicon photodiode reference detector. The $10 \mathrm{~nm}$ bandpass filter was used to minimize the effect of stray room light on the photodiode. The reference beam in both transmission systems was used to correct for fluctuations in laser light intensity. The majority of the laser light, in both the CTB and ETB systems, then traversed the containment vessel and was focused on a second optical filter and $1 \mathrm{~cm}$ silicon photodiode. The bandpass of the second optical filter was $10 \mathrm{~nm}$ and 1 $\mathrm{nm}$ for the CTB and ETB systems, respectively. The $1 \mathrm{~nm}$ bandpass filter 
will provide better discrimination against ambient room light, if it is required, but will also reduce the light level of the transmitted beam in the ETB system.

Figure 1. Schematic of the ETB transmission system

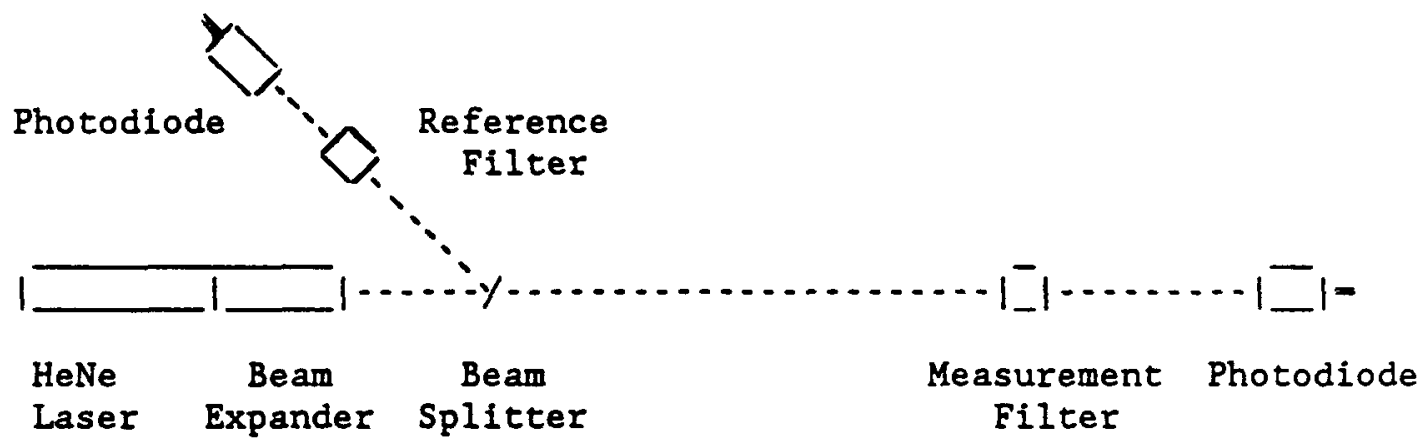

Table 3. Characteristics of the CTB and ETB Transmission Systems

\begin{tabular}{|c|c|c|c|c|}
\hline System & Laser & Beam Width & $\begin{array}{c}\text { Reference } \\
\text { Filter Bandpass }\end{array}$ & $\begin{array}{l}\text { Measurement } \\
\text { Filter Bandpass }\end{array}$ \\
\hline CTB & unpolarized & $0.6 \mathrm{~mm}$ & $10 \mathrm{~nm}$ & $10 \mathrm{~nm}$ \\
\hline ETB & polarized & $6.0 \mathrm{~mm}$ & $10 \mathrm{~nm}$ & $1 \mathrm{~nm}$ \\
\hline
\end{tabular}

Reflection of HeNe light off $\mathrm{UO}_{2} \mathrm{~F}_{2}$ particles and into two additional photodiodes was used to follow the $U_{6}$ release based on the light scatter technique. Two photodiodes were oriented orthogonally, and at the same vertical height, to the HeNe lasers. A $1 \mathrm{~nm}$ bandpass optical filter preceded one of the reflectance photodiodes; a $10 \mathrm{~nm}$ bandpass filter preceded the second reflectance detector.

The electronic current from all photodiodes was converted to voltage and amplified by the circuit presented in Figure 2. The series of circuit boards for the six photodiodes differed only by the magnitude of the load resistor $\left(R_{L}\right)$ in the feedback loop of the amplifier circuit. The amplification factor of each circuit is 
ORNL DWG 86-18327

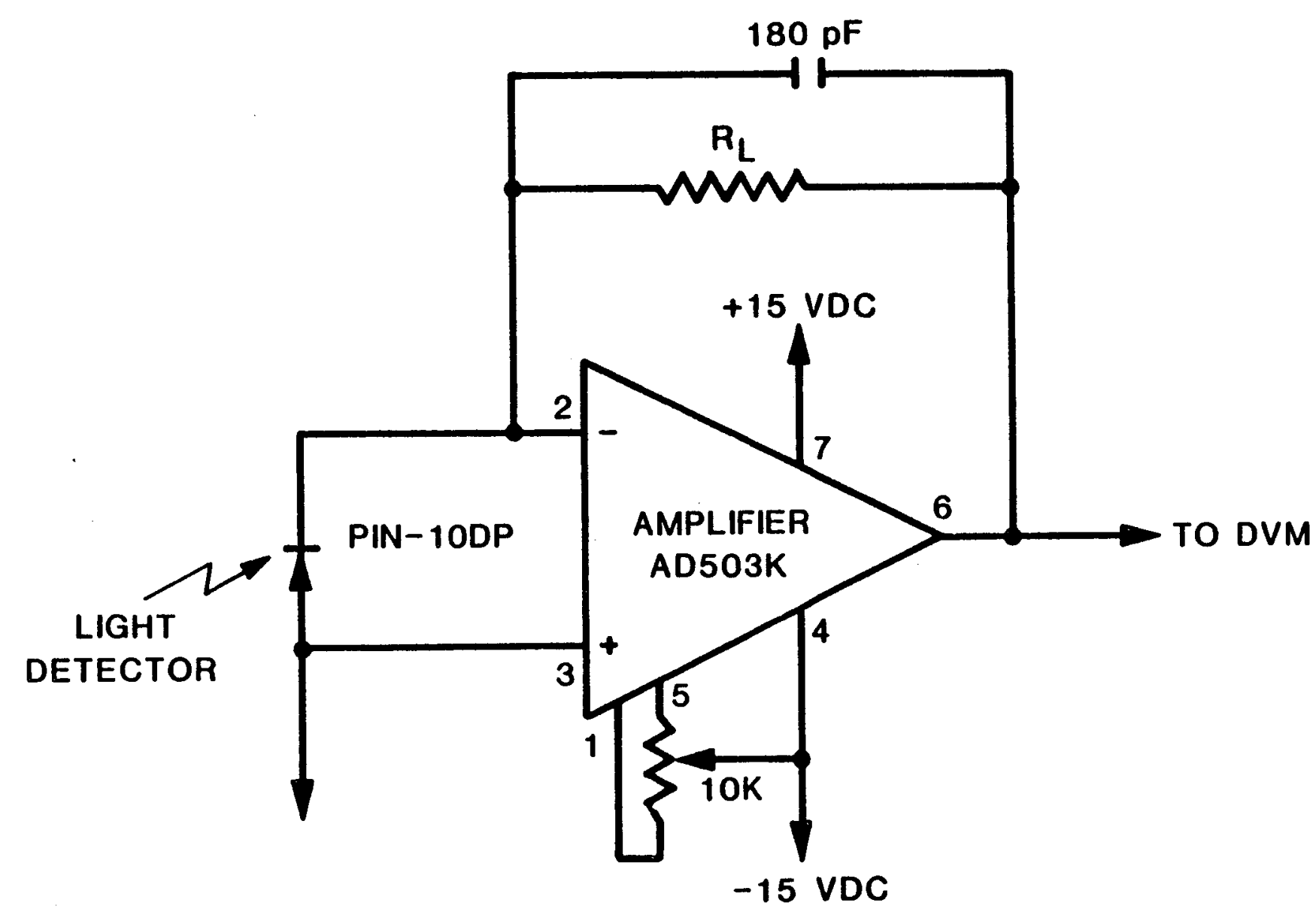

$a$

Figure 2. Detector amplifier circuit 
directly proportional to the value of $R_{L}$. The amplified outputs from the ETB reference and measurement diodes were additionally connected to a buffer and subtraction circuit. These circuits (Figure 3 ) were used to zero the voltage difference between the two ETB diodes prior to UF 6 release. The nulled response in the absence of $\mathrm{UF}_{6}$ corrects for light transmission losses through the viewing windows of the release vessel; the negative voltage output of the circuits during $U F_{6}$ release monitors the extent of light loss in the ETB laser system.

The analog output of each circuit was digitized using an HP 3497A Data Acquisition/Control Unit and a 3465A Digital Voltmeter. Data acquisition and statistical analysis were performed using an HP $85 \mathrm{~A}$ computer. During the release experiment, the HP system was programmed to acquire and average three optical readings taken at two second intervals for each of the six diodes. The optical data was then stored on magnetic tape; the data was also printed to provide a hard copy of experimental results. After the data had been taped and printed, there was a time delay of 10 seconds before the optical transmission and light scatter data was again collected.

The storage of the optical data on magnetic tape requires approximately one minute, which limits the rate that optical data can be acquired digitally. Therefore, the optical voltages from the measurement diodes in both the ETB and CTB laser systems were also followed with an analog strip chart recorder to observe photometric data continuously. A summary of the amplification and electronic monitoring of the photodiode optical signals is presented in Figure. 4.

\section{B. Gas Detector Tubes}

Gastec hydrogen fluoride detector tubes (catalog No. 17; lot No. QC-51135), containing the $\mathrm{pH}$ indicator 4-phenylazodiphenylamine as the selective reagent, were used in the release experiment. The indicator dye changes color from yellow to pink when exposed to acidic vapors. Migration distances for nominal HF concentrations of $0.5,1,2,5,10$, 15 , and $20 \mathrm{ppm}$ are indicated on the tube (Figure 5) for 4 pump strokes. Interpolation of scale readings were performed with reference to Figure 6. Concentrations greater than $20 \mathrm{ppm}$ were estimated by using fewer 
ORNL. DWG 86-18326R

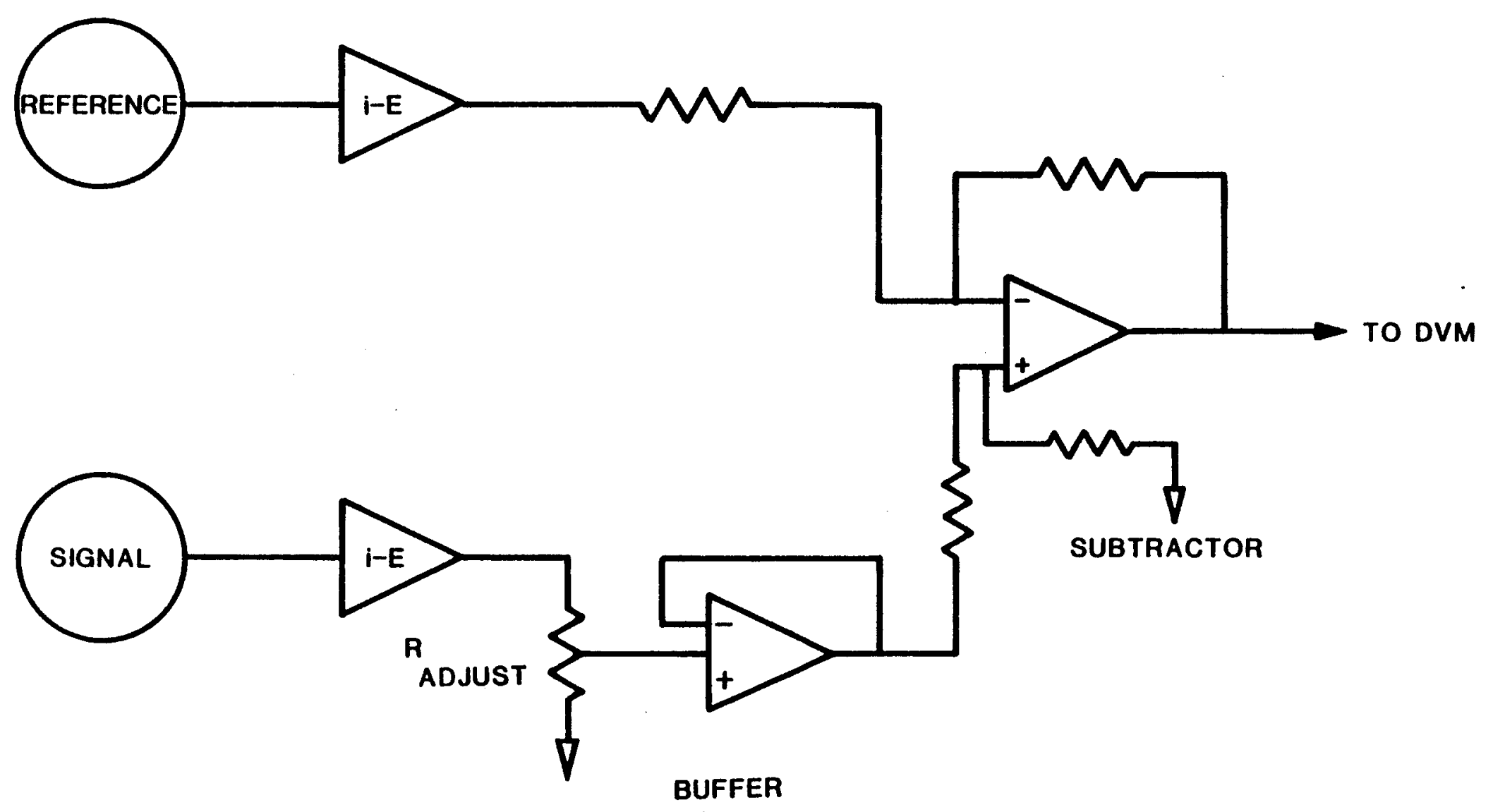

Figure 3. Block diagram of buffer and subtraction circuit 


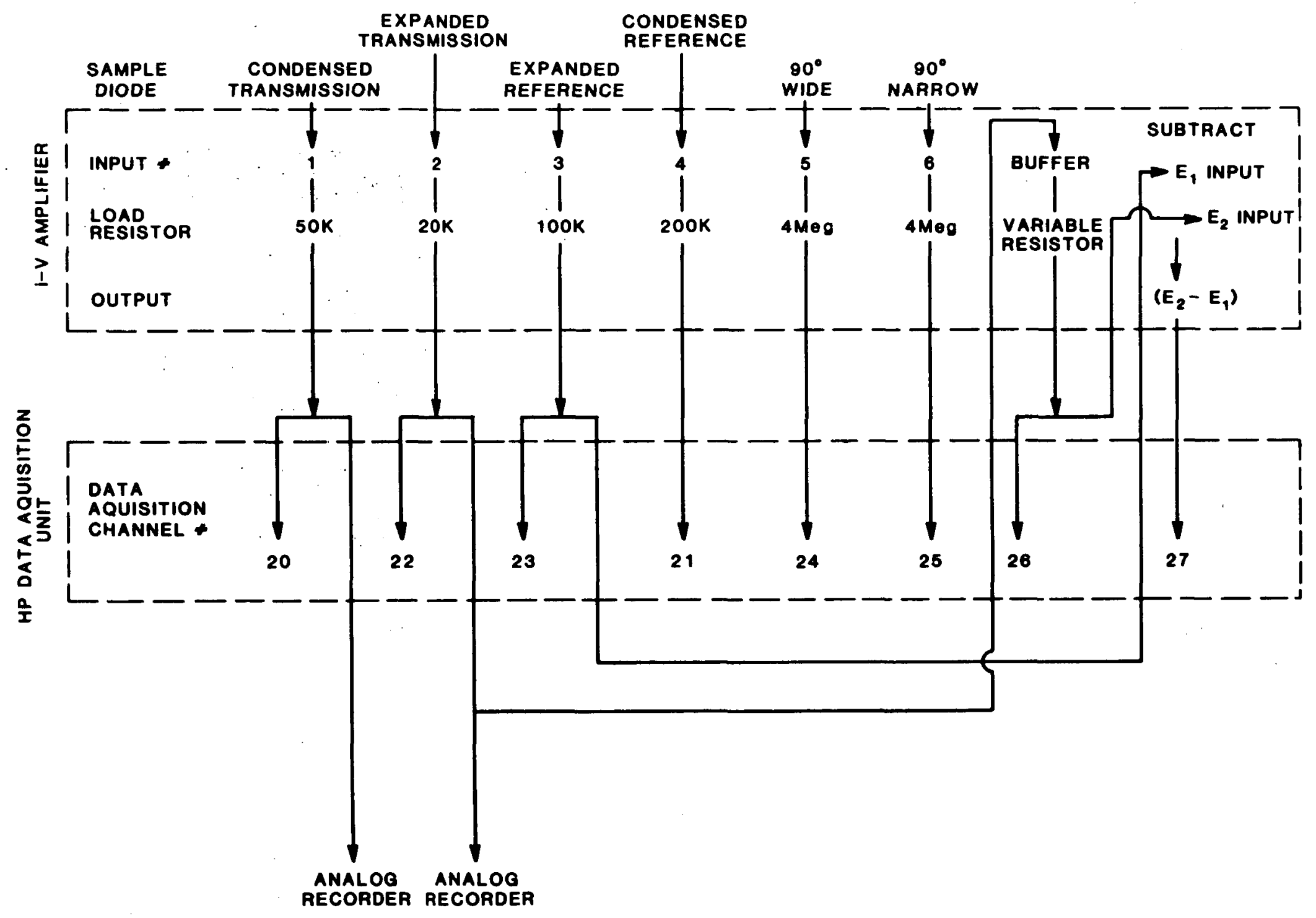

Figure 4. Summary of signal amplification and data output devices for CTB, ETB and Reflectance Photodiodes 


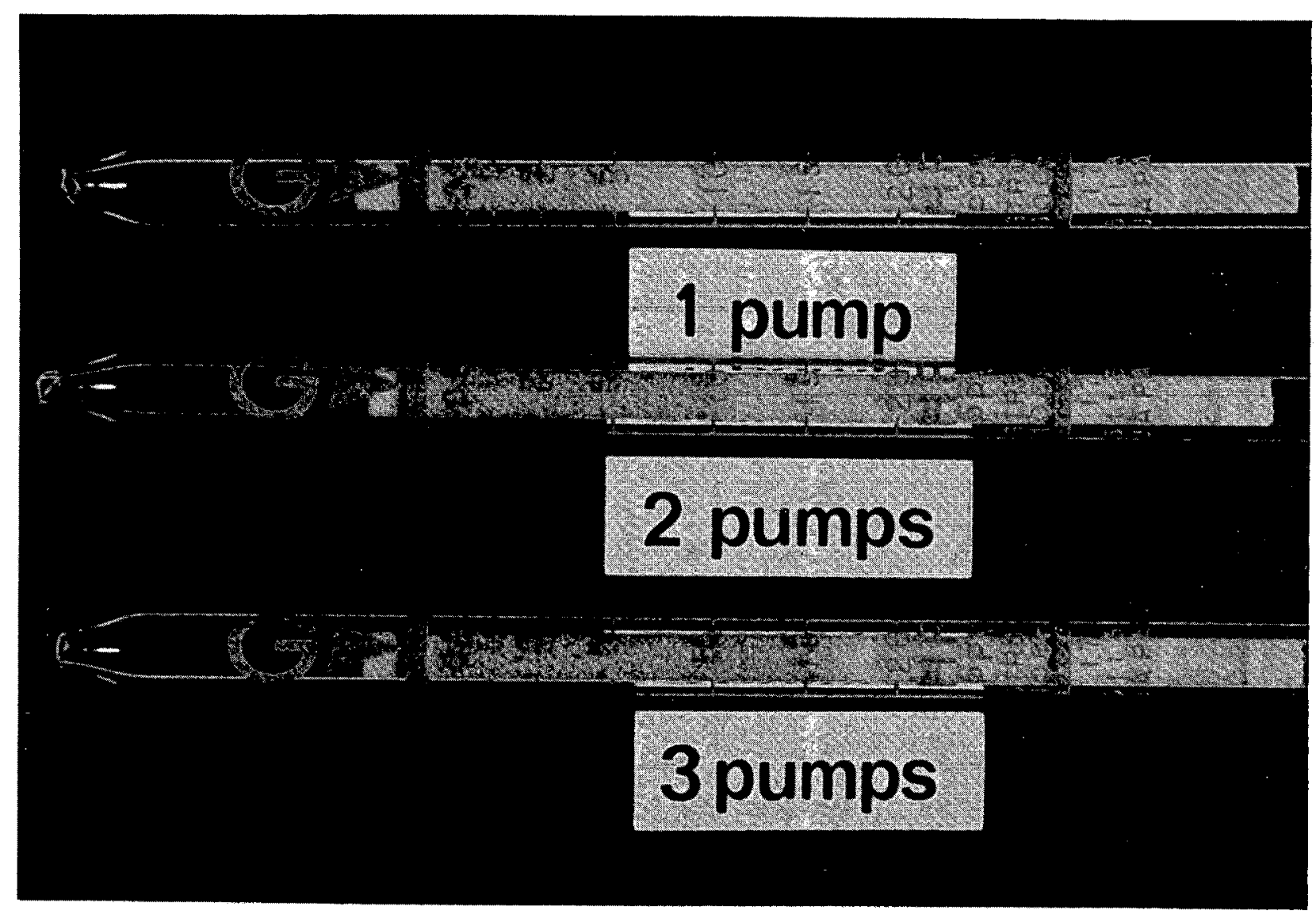

Figure 5. Photograph of Gastec HF detector tubes after sampling $\mathrm{UF}_{6}$ release containment chamber (see also Table 5 of text) 


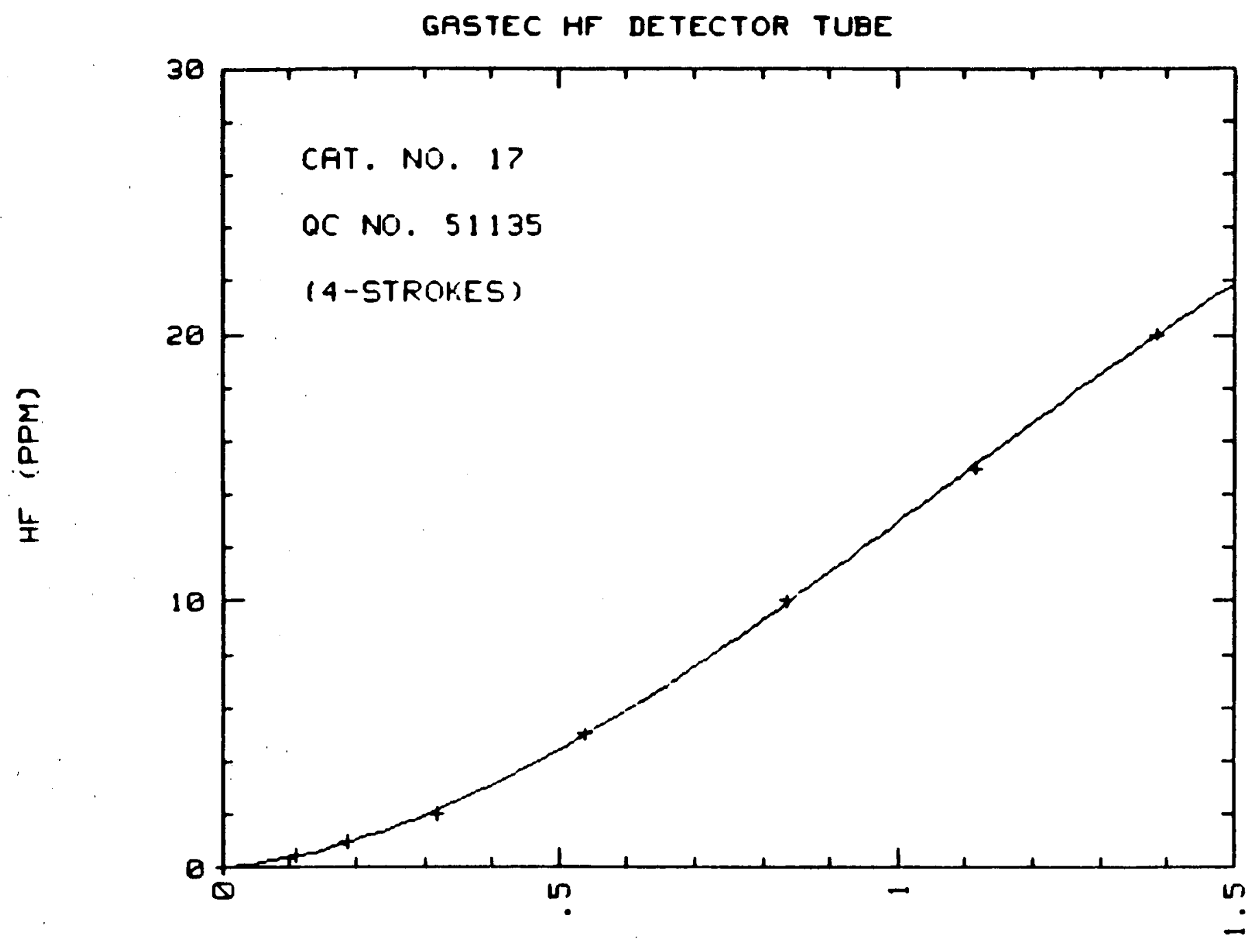

DISTANCE (IN.)

Figure 6. Nominal scale calfbration (HF, ppm) vs stain migration distance for Gastec HF detector tube 
than 4 pump strokes (< $400 \mathrm{~mL}$ sample) and multiplying the tube scale reading by the empirical corrections given in Table 4 (derived from the data of Table 6).

Table 4. Empirical scale reading correction factors for use with Gastec HF detector tubes

\begin{tabular}{cr} 
Pump Strokes & Correction \\
\cline { 2 - 2 } 1 & 4.76 \\
2 & 2.22 \\
3 & 1.37 \\
4 & 1.00
\end{tabular}

*HF - (Scale Reading) X (Correction Factor)

Literature enclosed with the tubes indicate that nominal scale readings must be corrected for the relative humidity of the gas being sampled (presumably, this is related to the co-adsorption of water vapor onto the silica gel matrix containing the indicator). However, the release on October 23, 1986, was performed under ambient conditions of $65^{\circ} \mathrm{F}$ and $508 \mathrm{RH}$, which (according to the tube manufacturer) requires no further correction of the data.

\section{Sensidyne HF Alert Monitor}

One week prior to the experimental release of $U F_{6}$, we replaced the sensor membrane cap (Sensidyne Part No. 7010163-1). One day prior to the test, the internal electrolyte solution (Sensidyne Part No. 7010686-7) was replenished. The sensor was calibrated using a flow cell assembly coupled to Kin-TEK Laboratories Model $570 \mathrm{C}$ Precision Gas Standards Generator (10). The Sensidyne probe was exposed to a continuous plug flow of $3 \mathrm{ppm} \mathrm{HF}$ vapor (from a permeation tube source) in 2.1 liters per minute dry nitrogen carrier gas. The sensor responded to this exposure with a time constant $\left(t_{1 / 2}\right)$ of $\approx 7$ seconds (i.e., exposed to $3 \mathrm{ppm} \mathrm{HF}$, the unit indicated a response of $1.5 \mathrm{ppm}$ within 7 seconds, and had attained $\approx 95 \%$ of its equilibrium response within 30 secionds) (10). When the probe was removed from the 
calibration cell, the sensor response recovered with a time constant of $\approx 21$ seconds.

\section{D. $\mathrm{UF}_{6}$ Release Facility}

The experimental release chamber is constructed from $3 / 4$ inch thick plexiglass sheets, with outside dimensions of $5 \mathrm{ft} X 6 \mathrm{ft} X 7 \mathrm{ft}$ (volume $210 \mathrm{ft}^{3}$ or $\approx 6 \mathrm{~m}^{3}$ ). The chamber and the mechanism for the rapid release of $U F_{5}$ therein have been described by Pickrell ( 9 ). The box and an exploded view indicating sampling ports and optical windows are illustrated in Figure 7. Windows for transmission and detection of the HeNe laser beam were made from plate glass, attached to the exterior surface of the chamber, covering $1 / 2$ inch holes bored into the chamber walls. Note in Figure 7 that the laser beams and "side" sampling port are located near the bottom of the chamber, relatively close to the release mechanism. On the other hand, the Sensidyne probe was placed at the top of the chamber, and penetrated into the inner dimension of the chamber of only $1-1 / 8$ inches. The "top" sampling port was adjacent to the Sensidyne probe.

The release experiment was initiated at 11:14 AM on October 23, 1986. Approximately $1.35 \mathrm{~g}$ of liquid $U_{6}(\approx 0.91 \mathrm{~g}$ as $U)$ was rapidly released into ambient air at $65^{\circ} \mathrm{F}\left(18^{\circ} \mathrm{C}\right)$ and 508 relative humidity. No forced convection was used to further disperse or homogenize the hydrolysis products formed within the enclosed chamber. A white cloud or smoke appeared instantaneously with the release of $U F_{6}$, and Initially rose (due to buoyant forces), followed by relatively slow mixing with the quiescent air, and agglomeration and eventual sedimentation of the particulate component of the aerosol.

E. Sampling and Chemical Analysis

At selected time intervals, the airborne materials within the chamber were sampled for chemical analysis. Samples were withdrawn from a point within 1-2 inches of the condensed laser beam with use of a sample probe (11-in. length X 1/4-in. ID steel tube) attached to a filter holder and pump assembly. Particulates were collected in air sampling cassettes (cat. No. MAW-P037AO, Millipore Corp., Bedford, MA) containing $0.8-\mu \mathrm{m}$ pore cellulose ester membranes. The membranes were 


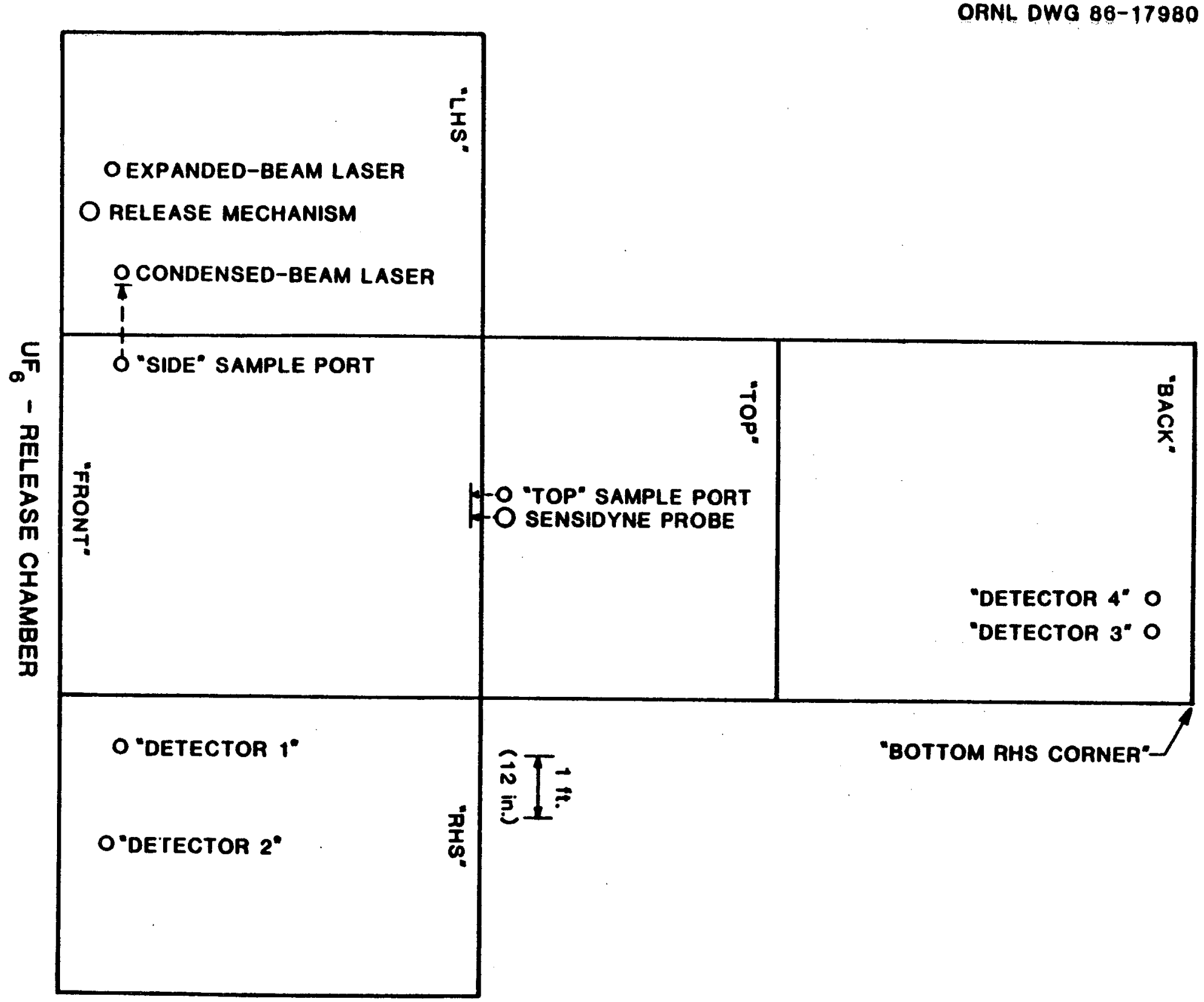

Figure 7. "Exploded" view of release chamber, indicating location of sampling and detection ports 
removed, extracted in $0.1 \mathrm{M} \mathrm{HCl}$ using ultrasonic agitation, and the extract was analyzed for total uranium via fluorometric assay.

Additional samples were taken using a dual membrane assembly for the separate collection of particulate and gaseous fluorides ( 8 ). Pre-wetted $1.0-\mu m$ pore Teflon prefilters (for $\mathrm{UO}_{2} \mathrm{~F}_{2}$ ) and formate-impregnated membranes (for HF) were extracted using acetate buffer. Extracts were assayed for fluoride ion with use of an ion-selective electrode. Aliquots of extracts were also assayed for uranium using the fluorometric procedure. Greater than 99.98 of the total $U$ collected was found on the prefilter, and the molar ratio of fluoride-to-uranium on the prefilter was found to be approximately 2.0 (consistent with the empirical formula $\mathrm{UO}_{2} \mathrm{~F}_{2} \cdot \mathrm{nH}_{2} \mathrm{O}$ ).

IV. EXPERIMENTAL RESULTS

\section{A. Photometric Detection}

Prior to $\mathrm{UF}_{6}$ release, several experiments were run to determine the stability of the optical signals and the effect of ambient room lighting on the light transmission and light scatter measurements. Not shown on the diagram of the containment vessel (Figure 7) is the location of an exterior building door relative to the photodiodes. The door opened directly opposite the faces of the light scatter diodes, orthogonal to the CTB and ETB measurement diodes and approximately $45^{\circ}$ to both reference diodes. By opening the exterior door, the ambient room light could be increased significantly. With both HeNe lasers turned off, the background dark currents of the photodiodes were measured when the door was opened and closed; this was compared with the optical voltage when the HeNe laser was turned on. Results in Table 5 suggest that the light scatter diodes were most affected by ambient room lighting. The scattered light level in the presence of an aerosol was so low that a large load resistor (1 Megn) was required to obtain a maximum amplified optical voltage of 0.1 volts. The large amplification factor also increases the magnitude of the background light signal so that the signal-to-noise ratio is poor for light scatter measurements. The light intensity in the transmission technique is great enough that only a modest-sized load resistor is 
required. If the bandpass of the optical filter is limited to $1 \mathrm{~nm}$, the effect of ambient room light is insignificant. When the reference signal was used to correct for changes in room lighting and fluctuations in laser intensity, the transmission signals from both the CTB and ETB signals did not vary by more than 18 .

Table 5. Effect of ambient room lighting on photodiode dark current Photodiode

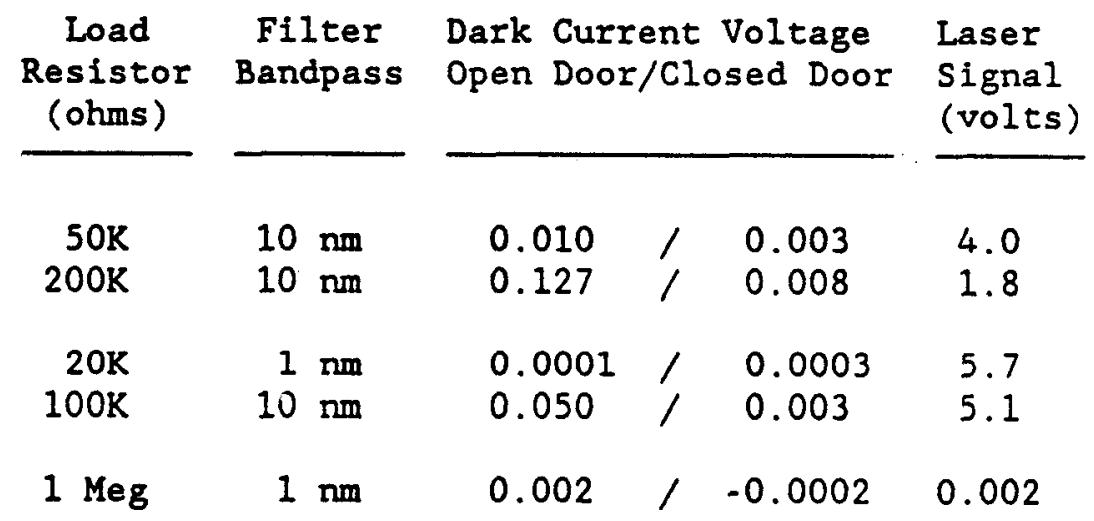

Figure 8 presents the analog and digitally acquired data taken during the release experiments. The discrete data points indicate prerelease optical voltages of $6.2,3.8$ and 0 volts for the ETB, CTB and Buffer-Subtraction circuit, respectively. Immediately after release, the analog ETB and CTB signals drop to less than 0.5 volts, increase sharply and finally stabilize one minute into the experiment as the aerosol disperses in the reaction vessel. The first digital data is acquired 1 minute into the experiment, after the distribution of the aerosol has stabilized. Not shown on this plot are the optical signals from the light scatter diodes. The aerosol was initially so dense that the laser beam was obscured to a point that the laser source did not provide enough light for scatter measurements. The light scatter signal, therefore, did not rise above background during this portion of the experiment.

The actual analog signals for the first four minutes of the experiment are presented in Figure 9. The CTB and ETB signals track each other, although the noise level in the expanded beam is larger. 
ORNL DWG 86-17979

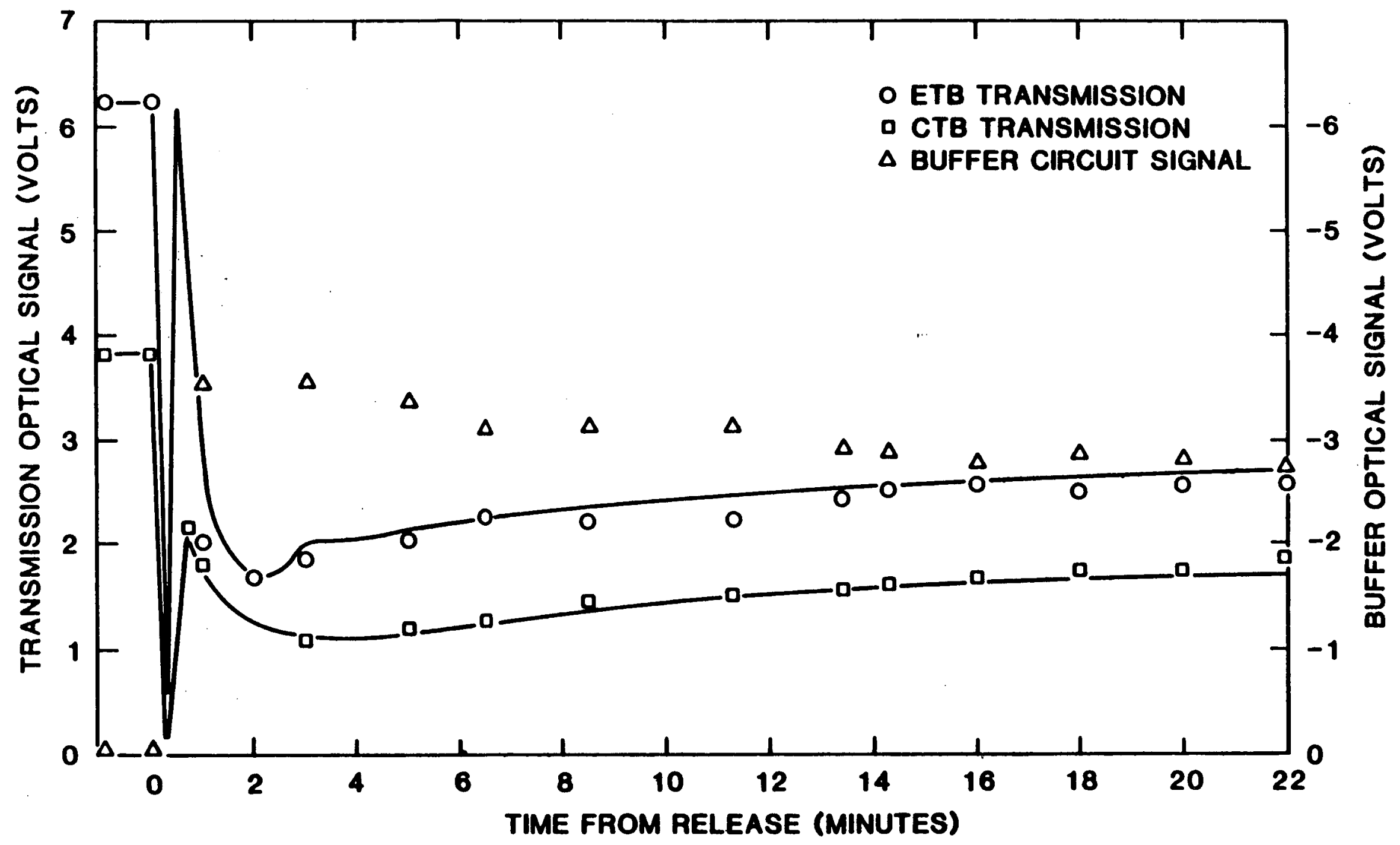

Figure 8. Digital and analog data for CTB and ETB optical signals after $\mathrm{UF}_{6}$ release 
ORNL DWG 86-17982

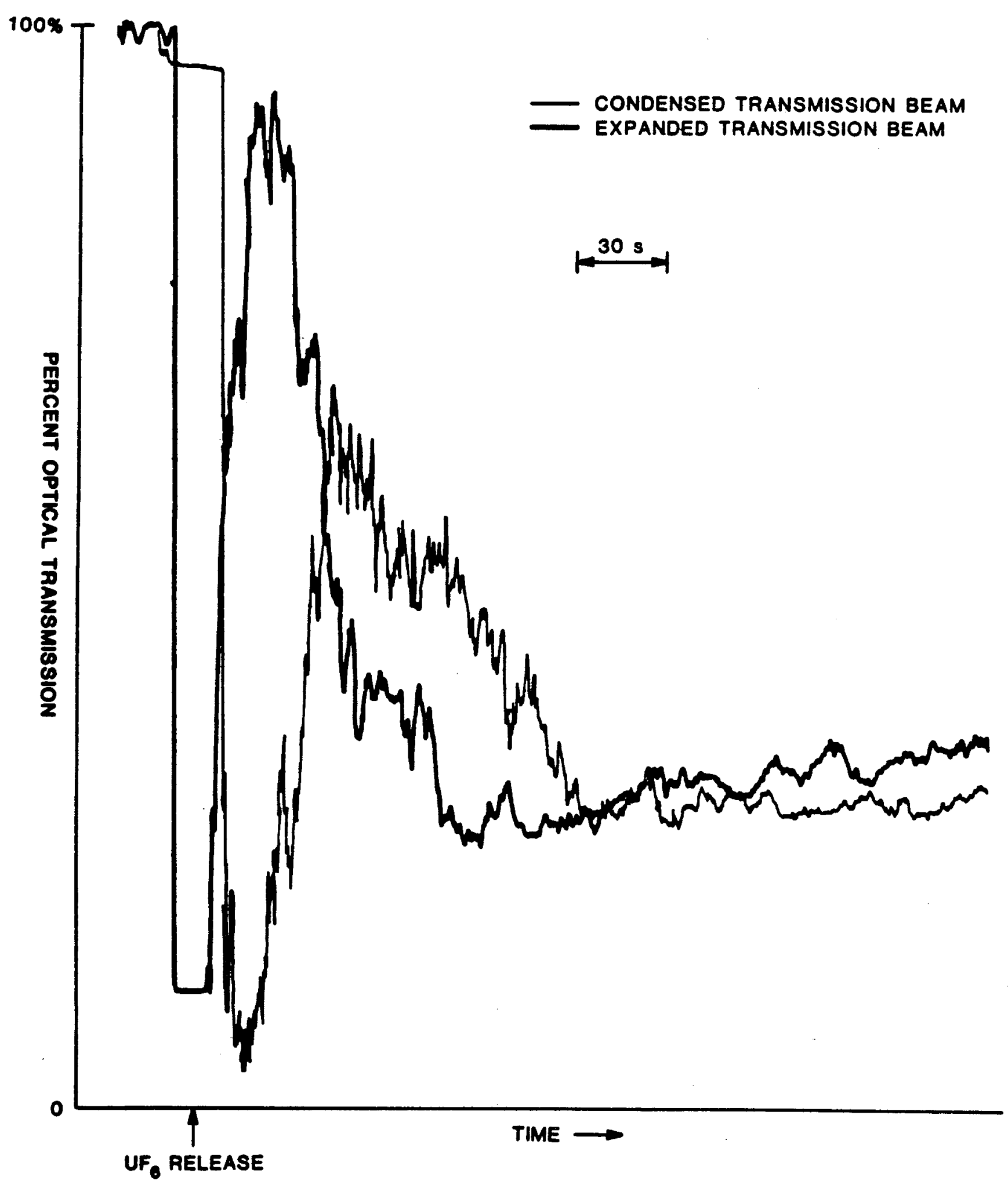

Figure 9. Tracing of a segment of analog laser light transmission data at initial time of $\mathrm{UF}_{6}$ release 
This may be due to the ability to detect changes in aerosol homogeneity in the larger sampling volume of the ETB system.

\section{B. Hydrogen Fluoride Detector Tubes}

Samples of aerosol were withdrawn from the "front" sample port (cf. Figure 7) using the Gastec detector tube and manual pump. Stain migration and estimated HF concentrations are summarized in Table 6 . The color contrast of the stain (red/pink against a yellow background, cf. Figure 5) was adequate for easy determination of the stain migration. The stains continued to slowly migrate after sampling (Table 7) and became more diffuse with time, presumably due to a chromatographic displacement with water adsorbed from the atmosphere.

Table 6. Results from sampling with use of Gastec HF detector tubes

\begin{tabular}{|c|c|c|c|c|c|}
\hline Tube \# & $\begin{array}{c}\text { Elapsed Time } \\
\text { (min.) }\end{array}$ & $\begin{array}{l}\text { Number of } \\
\text { Pump Strokes }\end{array}$ & $\begin{array}{c}\text { Stain Migration } \\
\text { (in.) }\end{array}$ & $\begin{array}{c}\text { Scale } \\
\text { Reading }\end{array}$ & $\begin{array}{l}\text { Nominal } \\
{[\mathrm{HF}], \mathrm{ppm}^{\circ}}\end{array}$ \\
\hline 2 & 3 & 1 & 1.00 & 12.8 & 61 \\
\hline $\begin{array}{l}6^{d} \\
7 \\
8\end{array}$ & $\begin{array}{l}18 \\
20 \\
22\end{array}$ & $\begin{array}{l}1 \\
2 \\
3\end{array}$ & $\begin{array}{l}0.50 \\
0.82 \\
1.15\end{array}$ & $\begin{array}{r}4.5 \\
9.6 \\
15.6\end{array}$ & $\begin{array}{l}21.4 \\
21.4 \\
21.4\end{array}$ \\
\hline $\begin{array}{r}9 \\
10 \\
11\end{array}$ & $\begin{array}{l}48 \\
50 \\
52\end{array}$ & $\begin{array}{l}1 \\
2 \\
4\end{array}$ & $\begin{array}{l}0.35 \\
0.55 \\
0.93\end{array}$ & $\begin{array}{r}2.4 \\
5.2 \\
11.5\end{array}$ & $\begin{array}{l}11.4 \\
11.6 \\
11.5\end{array}$ \\
\hline 12 & 151 & 4 & 0.60 & 6.0 & 6.0 \\
\hline 13 & 249 & 4 & 0.58 & 6.0 & 6.0 \\
\hline 14 & 1351 & 4 & 0.45 & 3.8 & 3.8 \\
\hline
\end{tabular}

\footnotetext{
a Time elapsed from instant of $\mathrm{UF}_{6}$ release

b Interpolated using Figure 6

c Nominal [HF] - (Scale Reading) $x$ (Correction Factor), where correction factors are given in Table 4

d Tubes $6-8$ are illustrated in Figure 5.
} 
The accuracy of the detector tubes for monitoring HF in air has not yet been validated in this laboratory, but it is apparent from Table 6 that they possess good sensitivity under the ambient conditions of the experimental release $\left(65^{\circ} \mathrm{C}\right.$ and $\left.508 \mathrm{RH}\right)$. The determination of the effect of varying conditions of temperature and humidity upon initial stain production by $\mathrm{HF}$ vapor is currently in progress and will be reported separately.

Table 7. Post-sampling stain migration on Gastec HF detector tubes Stain Migration (inches)

$\begin{array}{cccc}\text { Tube No.* } & \text { Day 1 } & \text { Day 10 } & \text { Day 17 } \\ 2 & 1.00 & 1.15 & 1.20 \\ 9 & 0.35 & 0.45 & 0.50 \\ 10 & 0.55 & 0.71 & 0.76 \\ 11 & 0.93 & 1.11 & 1.17\end{array}$

*see also Table 6

\section{Sensidyne HF Alert Monitor}

In order to confirm the accuracy of the calibration (see Section IIIC) and to demonstrate that the device responds selectively to $\mathrm{HF}$ rather than total fluoride, a sample of aerosol was collected near the Sensidyne probe with use of a dual membrane assembly for the separate collection of particulate $\left(\mathrm{UO}_{2} \mathrm{~F}_{2}\right)$ and gaseous (HF) fluoride; the results are given in Table 8 . The response of the probe, calibrated with use of HF vapor, was in good agreement with the chemical assay for gaseous fluoride. Note that the molar ratio of fluoride to uranium on the prefilter is 2.0 , consistent with $\mathrm{UO}_{2} \mathrm{~F}_{2}$ hydrate as the particulate species (cf. Equation 1). Note also that the stoichiometric equation (1) predicts a yield of two moles of gaseous fluoride (HF) for each 
mole of particulate fluoride $\left(\mathrm{UO}_{2} \mathrm{~F}_{2}\right)$, assuming homogeneous dispersion of reaction products. In contrast, the data of Table 8 indicate that only $\approx 0.4$ moles of $\mathrm{HF}$ per mole of $\mathrm{UO}_{2} \mathrm{~F}_{2}$ were collected after $\approx 34$ minutes at the top of the chamber; this indicates that, without forced convection, the HF component of the aerosol was not homogeneously dispersed at the time of sampling.

The response of the Sensidyne HF Alert assembly versus time elapsed from the instant of $U F_{B}$ release is shown in Fig. 10. Also shown is the

Table 8. Comparison of Sensidyne HF Alert response to chemical composition

Sensidyne HF Alert ${ }^{1}$ airborne fluoride

Chemisorption ${ }^{4}$
Chemical Sampling \& Analysis ${ }^{2}$

$\frac{\overline{a i r b o r n e} \text { uranium }}{\text { Prefilter }^{3}} \frac{\text { airborne fluoride }}{\text { Chemisorption }^{4}}$

$\begin{array}{cc}4.0 \mathrm{ppm} \mathrm{HF} & 3.6 \mathrm{ppm} \mathrm{HF} \\ \left(3.2 \mathrm{mg} \mathrm{F} / \mathrm{m}^{3}\right) & 50.2 \mathrm{mg} \mathrm{U} / \mathrm{m}^{3} 0.019 \mathrm{mg} \mathrm{U} / \mathrm{m}^{3} \quad 8.0 \mathrm{mg} \mathrm{F} / \mathrm{m}^{3}\left(2.8 \mathrm{mg} \mathrm{F} / \mathrm{m}^{3}\right)\end{array}$

1. Previously calibrated with permeation device, using dry nitrogen carrier gas

2. 17.2 liters of gas at $18^{\circ} \mathrm{C}$ sampled during the interval of $32-36$ minutes subsequent to $\mathrm{UF}_{6}$ release. Sample was taken at "top" port, near Sensidyne probe (see Figure 8 ).

3. Teflon prefilter, $1.0 \mu \mathrm{m}$ pore

4. Formate-impregnated cellulose acetate chemisorption filter, $5.0 \mu \mathrm{m}$ pore

response of the assembly to a prior release on May 19, 1986 (see Table 9 ), in which forced convection was provided by a small fan (nominal 2.5 $\mathrm{m}^{3} / \mathrm{min}$ flow velocity) for 3.5 minutes subsequent to the release. With forced convection, the Sensidyne unit indicated a $3 \mathrm{ppm} H F$ threshold value within $\approx 15$ seconds; note also in Figure 11 that HF concentration 
ORNL DWG 86-17887

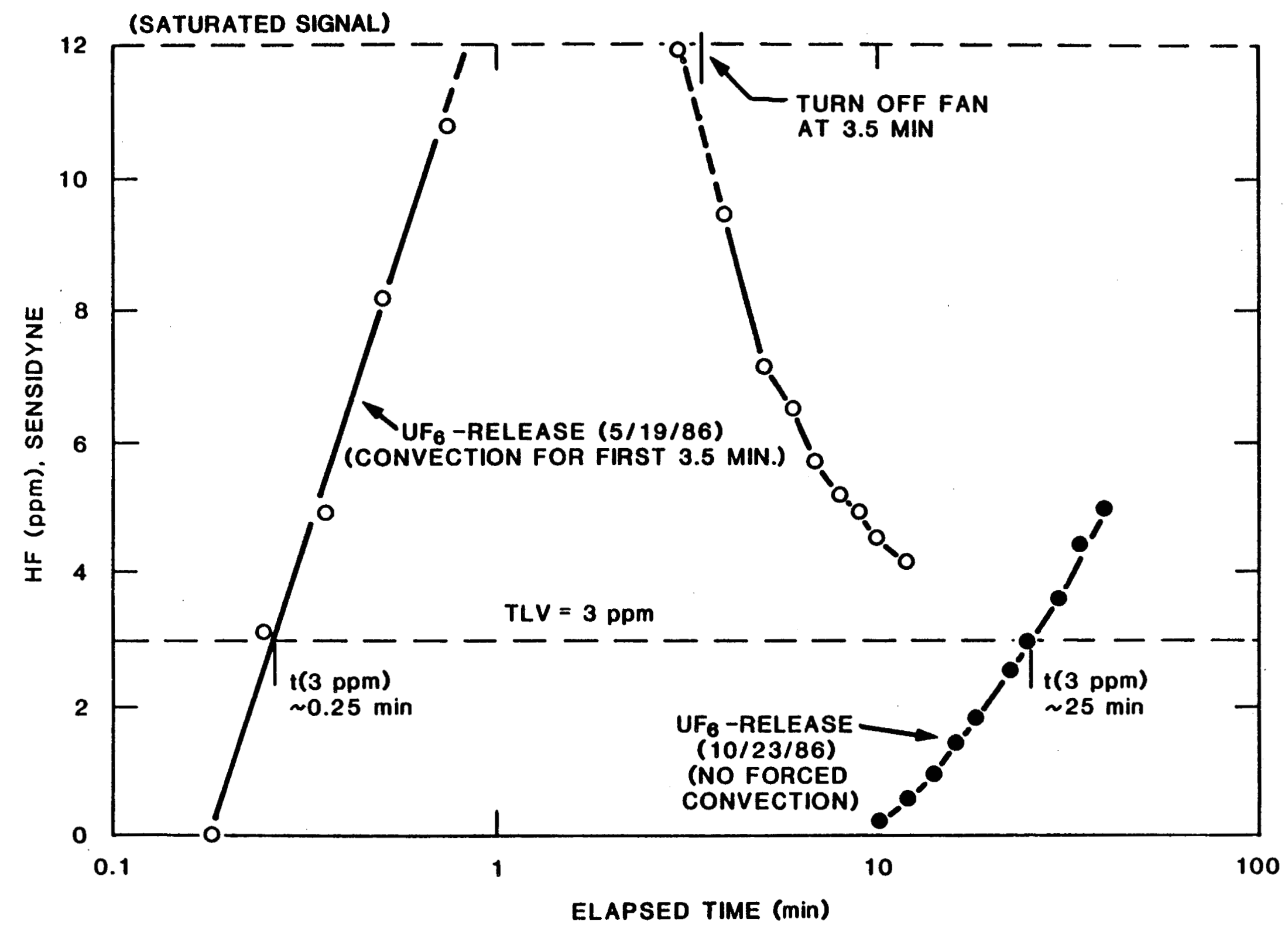

Figure 10. Response of Sensidyne HF alert to experimental release of $\mathrm{UF}_{6}$ : effect of forced convection within chamber 
near the top of the chamber rapidly declined after forced convection was terminated. In contrast, the release with no forced convection required approximately 100 -times as long to indicate a $3 \mathrm{ppm}$ threshold value at the top of the chamber; peak response was $5.7 \mathrm{ppm}$ after $\approx 100$ minutes elapsed time (cf. Table 6 for nominal HF concentrations near the bottom of the chamber as indicated with use of the Gastek gas detector tubes.) These data suggest that hydrated HF tends to sediment near the bottom of the chamber and does not homogeneously disperse without forced convection.

Table 9. Experimental releases of $U F_{B}$ into a $6 \mathrm{~m}^{3}$ Chamber

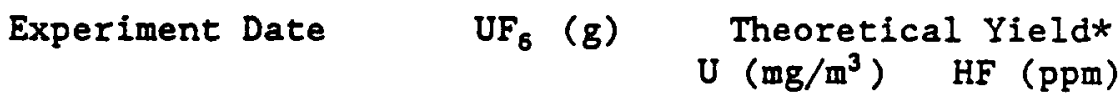

\begin{tabular}{llll}
\hline May 19, 1986 & 0.98 & 163 & 45 \\
October 23, 1986 & 1.35 & 225 & 62 \\
\hline
\end{tabular}

*Assuming complete hydrolysis and dispersion of reaction products with the following stoichiometry:

$$
\mathrm{UF}_{6}+2 \mathrm{H}_{2} \mathrm{O} \cdots-\rightarrow \mathrm{UO}_{2} \mathrm{~F}_{2}+4 \mathrm{HF}
$$

\section{COMPARISON OF DETECTION DEVICES AND THEIR RESPONSE}

As the laser beam propagates through a medium containing suspended particles, its intensity is attenuated to an extent dependent upon the concentration of scattering centers and the sampling pathlength. This represents turbidometric measurement, which usually obeys a Beer's law relationship:

$$
A=\log _{10}\left(I_{0} / I_{t}\right)=k b c
$$

where $A$ is absorbance, $I_{0}$ is the intensity of the incident beam, $I_{t}$ is the intensity of the transmitted beam, $b$ is the pathlength, $c$ is a measure of concentration, and $\mathrm{k}$ is a proportionality constant. 
In Figure 11, the absorbance signals for the CTB and the ETB lasers are compared to the airborne uranium concentration as a function of time elapsed from the instant of $U F_{6}$ release. (Note: intensities used for the computation of absorbance were taken from the continuous analog signals, a portion of which is shown in Figure 9.)

As shown in Figure 11, absorbance of the laser beam is maximum (i.e., transmission of light is minimal) before the peak concentration of airborne uranium occurs, suggesting that species other than particulate uranium may contribute to the observed laser light attenuation. Figure 12 compares the absorbance of the laser light to the apparent HF concentration, as determined with use of the Gastec HF gas detector tube. Apparent HF concentration near the bottom of the chamber peaks early, as does the laser beam response. It is thus probable that condensable hydrated HF also contributes to the laser beam attenuation by light scatter.

The sensitivity for monitoring $\mathrm{UO}_{2} \mathrm{~F}_{2}$ by laser light attenuation can be estimated by comparing the observed absorbance with uranium concentration for all data occurring at times greater than 100 minutes after $\mathrm{UF}_{6}$ release. Beyond this time, the contribution of HF to light attenuation is minimal. Figure 11 indicates that there is a loss of 5 milliabsorbance (mA) per $\mathrm{mg} U / \mathrm{m}^{3}$, using a 6 -foot optical path length. Thus the proportionality constant, $k$, is equivalent to approximately $0.9 \mathrm{~mA}$ per $\mathrm{mg} U / \mathrm{m}^{3}$ per foot for either the CTB or ETB laser system.

If one assumes that a 3 light loss (13 mA) can be detected with the transmission system, then a minimum of $3.8 \mathrm{mg} U\left(5.6 \mathrm{mg} U F_{6}\right)$ release could be detected in an autoclave having a $1.5 \mathrm{~m}^{3}$ (52 $\mathrm{ft}^{3}$ ) volume and 4 foot optical path. Because HF also contributes to light loss during the release, the actual sensitivity to $U F_{6}$ release will be slightly greater.

\section{RECOMMENDATIONS}

\section{A. Laser $\mathrm{UF}_{6}$ Release Monitor}

Monitoring $\mathrm{UF}_{6}$ release based on the 90 -degree scatter of laser light is not recommended. This technique failed for two reasons: first, the scattered signal is so weak that ambient room lighting contributes significantly to the total signal, even when the best 
ORNL DWG 86-17889R

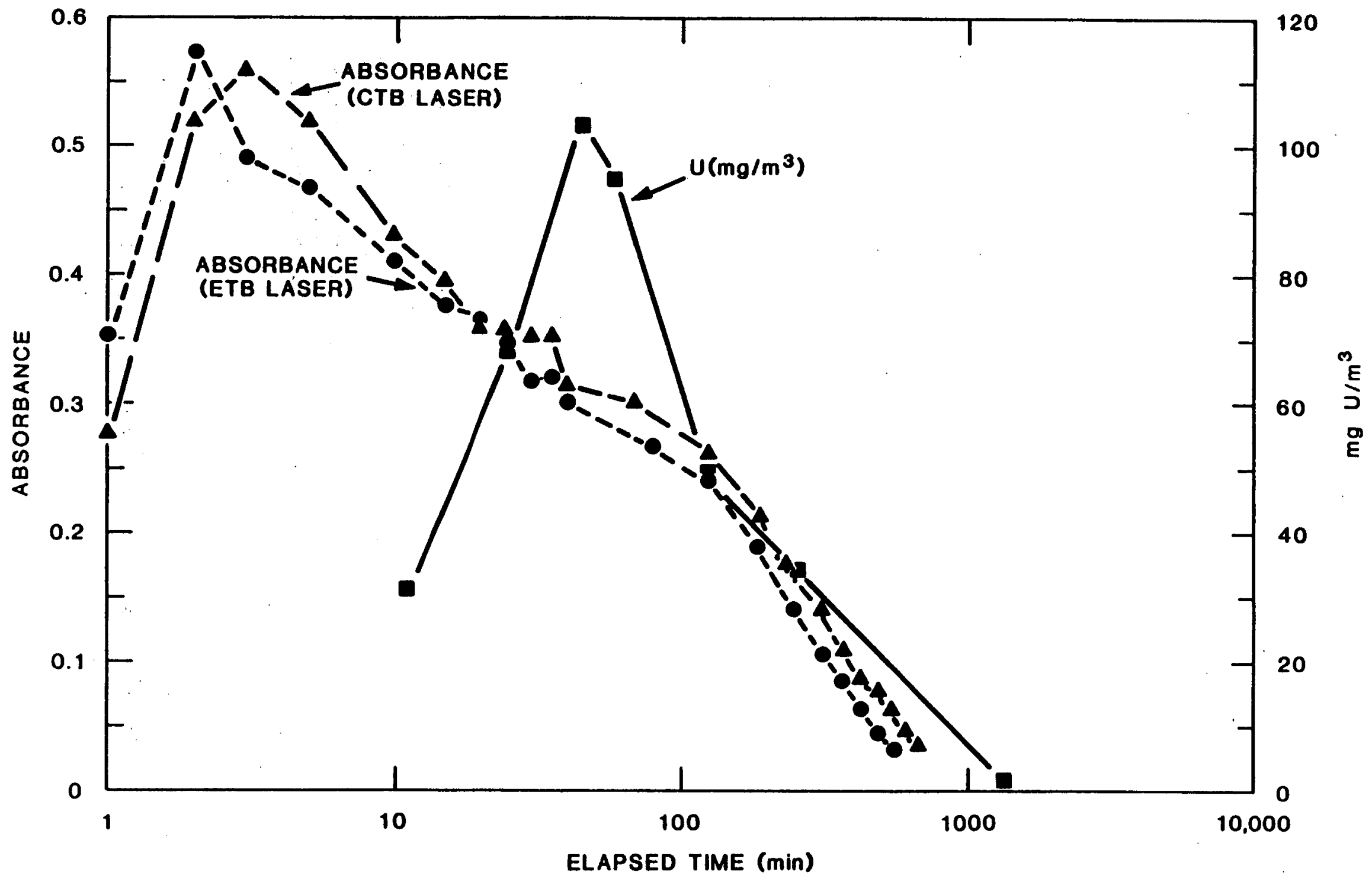

Figure 11. Comparison of airborne uranium concentration (sampled at

"side" port, CF. Fig. 7) vs absorbance of laser beam during

$\mathrm{UF}_{6}$-release experiment 
optical. filtering is used. Second, when there is a sudden, large release of $U F_{6}$, the laser beam is totally obscured and little scattered light can reach the detector. This can result in a false negative signal from the release monitor.

The UF 6 release monitor can be based on the attenuation of a laser beam traversing the containment vessel. The beam can be expanded for monitoring a larger volume of the vessel; however, if there is forced convection this probably is not necessary. According to Figure 12 there is little difference in sensitivity between the ETB and CTB system, although the ETB system data was slightly noisier during the release experiment. Both the reference and measurement photodiodes should be preceded by a 1 nm bandpass optical filter to minimize the interference caused by ambient room lighting during monitor operation.

The optical signals from the photodiodes can be measured either by analog circuitry or digitally. An analog signal provides an instantaneous response to $U F_{b}$ release. However, a 5-second response time should be possible with the digital HP data acquisition system if data is not stored on magnetic tape or logged with a printer. Faster response times can be obtained with other brands of digital data acquisition equipment. Several controls should be available to 1) check for voltage over-range and subsequent amplifier saturation, 2) correct the ambient room light contribution and autoclave port window fouling, and 3) check for laser power level and photodiode sensitivity. Because of the amount of time that would be required to design these features with analog circuitry, it may be advisable to use an analog amplifier circuit for the photodiode current, followed by an analog-to-digital converter and computer. Development of control features through computer software may prove less time consuming and more economical.

\section{B. HF Gas Detector Tube}

The Gastec HF detector tubes have been shown to be very sensitive to $\mathrm{UF}_{6}$ hydrolysis products under the conditions of the experimental release (see Figure 12). The stain migration distance for a given concentration of $\mathrm{HF}$ is expected to increase at elevated temperatures and at lower absolute humidities. The performance of these detectors 
ORNL DWG 86-17988R

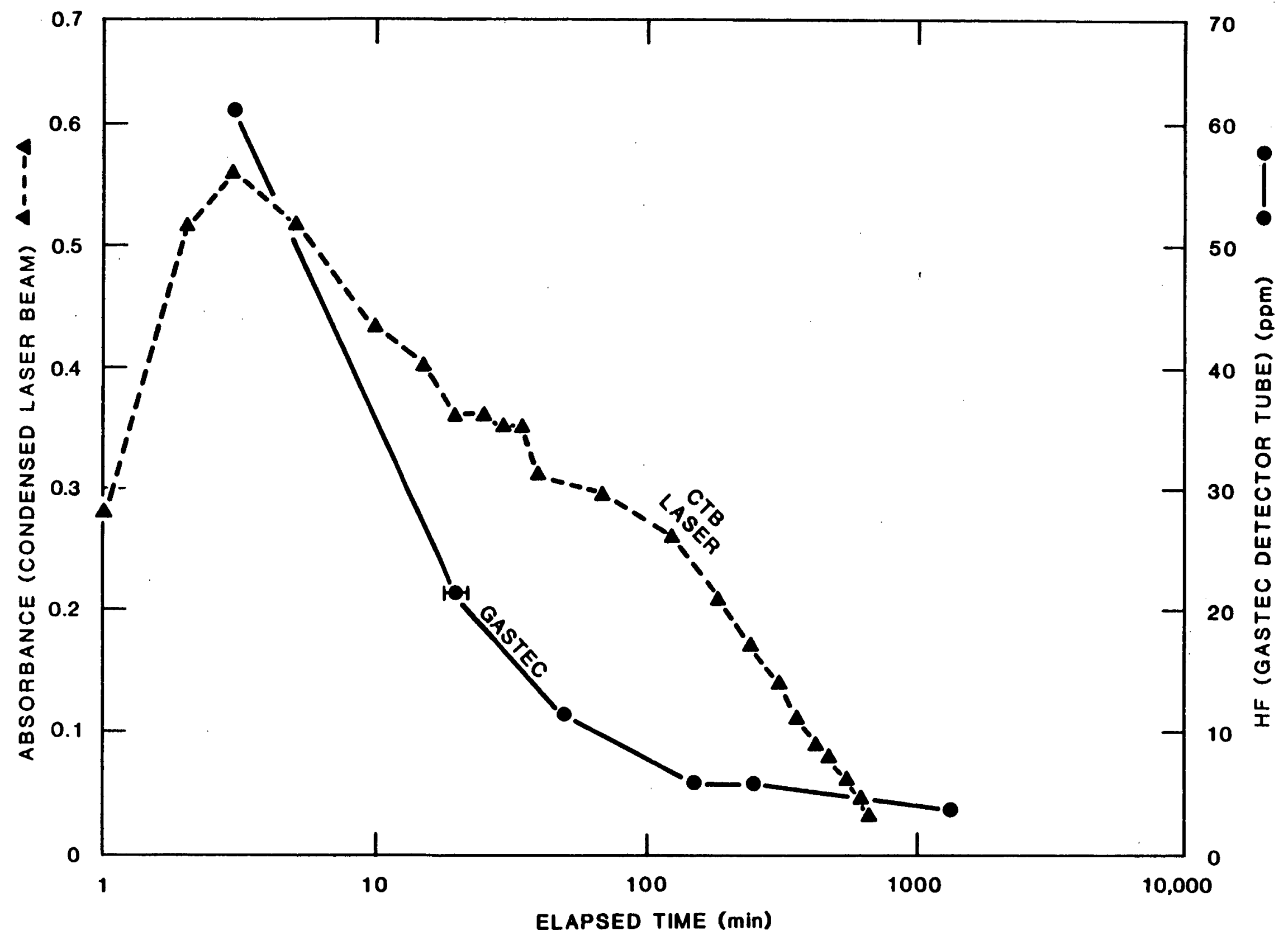

Figure 12. Comparison of airborne HF concentration (sampled at "side" port, using Gastec HF detector tubes) v $\underline{s}$ absorption of laser beam during $\mathrm{UF}_{6}$-release experiment 
under the ambient conditions within an autoclave or reactor remains to be evaluated.

\section{Sensidyne HF Alert Monitor}

This device has been demonstrated to have good sensitivity and a rapid response toward HF vapor (10). However, as discussed in Section IV, hydrated HF vapor or mist appears to remain near ground level in the absence of forced convection. Therefore, for accurate monitoring of HF we recommend use of forced convection near the sensor or active transport of sample to the sensor membrane.

\section{ACKNOWLEDGEMENTS}

We would like to thank the following colleagues from Martin Marietta Energy Systems, Inc., for their contributions to this investigation: P. W. Pickrell for his cooperation in performing the release of $U F_{6}$ in the experimental chamber, E. C. Angel for his assistance in the set-up and sample collection, and L. N. Klatt for the design and fabrication of the analog circuitry. 


\section{REFERENCES}

1. T. Okamoto and R. Kiyose, "Evaluation of Uranium Hexafluoride Vapor Release in a Postulated Accident," J. Nucl. Sci. Technol., 15(6), 455 (1978).

2. Nuclear Regulatory Commission, "Rupture of Model 48Y UF6 Cylinder and Release of Uranium Hexafluoride, Sequoyah Fuels Facility, Gore, Oklahoma, January 4, 1986. Volume 1," NUREG-1179-Vol. 1 (Feb. 1986).

3. DOE Incident Investigation Board, "Investigation of January 19 , 1986 Failure of Reaction Vessel at the Feed Materials Production Center (FMPC) UF 6 to UF 4 reduction facility, Fernald, Ohio," DOE-ORO-875 (June 1986).

4. R. A. Just and V. S. Emler, "Generic Report on Health Effects for the U. S. Gaseous Diffusion Plants," K/D 5050, Section VII, Part 1 (June 1984).

5. C. K. Bayne and W. D. Bostick, "Particle Size Distributions Formed by Atmospheric Hydrolysis of Uranium Hexafluoride," ORNL/CSD/TM-228 (Jan. 1985).

6. W. D. Bostick, W. H. McCulla, and P. W. Pickrell, "Sampling, Characterization, and Remote Sensing of Aerosols Formed in the Atmospheric Hydrolysis of Hexafluoride," K/PS-5052 (May 1984).

7. W. H. McCulla, "Determination of the Rate of HF Hydration and the Effects of HF on Moisture Condensation," K/PS-155 (April 30, 1982).

8. W. D. Bostick, W. H. McCulla, and P. W. Pickrell, "Sampling, Characterization, and Remote Sensing of Aerosols Formed in the Atmospheric Hydrolysis of Uranium Hexafluoride," J. Environ. Sci. Health, 20(3), 369 (1985).

9. P. W. Pickre11, "Characterization of the Solid, Airborne Materials Created by the Interaction of $U_{6}$ with Atmospheric Moisture in a Contained Volume," K/PS-915 (Dec. 1984).

10. W. D. Bostick and E. C. Angel, MMES Internal Correspondence to T. H. Hamilton, June 13, 1986. 

ORNL/TM-10341

INTERNAL DISTRIBUTION

1. V. Allen

2. E. C. Angel

3. E. J. Barber

4-6. D. T. Bostick (3)

7-9. W. D. Bostick (3)

10. G. L. Bowers

11. J. T. Bradbury, III

12. J. A. Carter

13. H. T. Conner, Jr.

14. B. Crump

15. R. L. Dearstone

16. L. V. Gibson

17. G. L. Grametbauer

18. G. F. Hagan

19. T. H. Hamilton

20. R. A. Just

21. G. J. Kidd, Jr.

22. L. N. Klatt
23. W. L. Maddox

24. M. E. Ohara

25. J. T. Patton

26. P. W. Pickrell

27. J. M. Ramsey

28. J. Rayside

29. F. R. Ruppel

30. T. W. Semple

31. W. D. Shults

32. R. H. Stevens

33. J. D. Stout

34. W. G. Wimpsett

35. Central Research Library

36. Document Reference Section

37. K-25 Information Resource Center

38-39. Laboratory Records

40. Laboratory Records - RC

41. ORNL Patent Office

\section{EXTERNAL DISTRIBUTION}

42. L. Elikan, Westinghouse Materials Company of Ohio, P. O. Box 398704, Cincinnati, OH 45239

43. M. J. Orlett, Portsmouth Gaseous Diffusion Plant, Piketon, $\mathrm{OH}$ 45661

44. A. J. Saraceno, Portsmouth Gaseous Diffusion Plant, Piketon, $\mathrm{OH}$ 45661

45. R. W. Simi, Westinghouse Materials Company of Ohio, P. O. Box 398704, Cincinnati, OH 45239

46. H. H. Thomas, Portsmouth Gaseous Diffusion Plant, Piketon, $\mathrm{OH}$ 45661

47. Office of Assistant Manager for Energy Research and Development, USDOE - ORO

48-78. Technical Information Center, Oak Ridge, TN 37830 